\title{
Fresh gas flow in the Bain circuit during laparoscopy
}

Twenty-two women were studied during laparoscopy with abdominal insufflation of carbon dioxide. A Bain anaesthetic breathing circuit was used with a fresh gas flow (V) $\mathrm{ml} \cdot \mathrm{min}^{-1} \cdot \mathrm{kg}^{-1}$, and controlled ventilation was applied with a minute ventilation $(\dot{V} E)$ of $175 \mathrm{ml} \cdot \mathrm{min}^{-1} \cdot \mathrm{kg}^{-1}$. Arterial blood gases were analysed at the end of the operation. Nineteen of the women (86 per cent) were found to have a $\mathrm{PaCO}_{2}$ within the range for normocapnia (i.e., $4.7-5.9 \mathrm{kPa}(35-45 \mathrm{mmHg}))$, two were hypocapnic with a $\mathrm{PaCO}_{2}$ of 4.4 and $4.5 \mathrm{kPa}$ (33 and 34 $\mathrm{mmHg}$ ) respectively and one was found to have a $\mathrm{PaCO}_{2}$ of 6.2 $\mathrm{kPa}(46.5 \mathrm{mmHg})$. It was concluded that the carbon dioxide absorbed from the abdomen during laparoscopy demands fresh gasflows that are higher than normally used in the Bain circuit if a $\mathrm{PaCO}_{2}$ within the normal range is to be obtained. A simultaneous increase in $\dot{V} F G$ and $\dot{V} E$ of about 45 per cent is sufficient to achieve normocapnia.

\section{Key words}

CARBON DIOXIDE: absorption, blood levels, insufflation; EQUIPMENT: circuits, non-breathing, Bain; SURGERY: gynaecological, laparoscopy, insufflation; VENTILATION: carbon dioxide tension, intermittent positive pressure breathing.

From the Department of Anaesthesia and Intensive Care, Östersund Hospital, Östersund, Sweden.

Address correspondence to: Dr. L. O. Jonsson, Department of Anaesthesia and Intensive Care, S-831 83 Östersund Hospital, Sweden.
In a Bain anaesthetic circuit (coaxial Mapleson D system), rebreathing of carbon dioxide will occur if the fresh gas flow ( $\left.\dot{V}_{F G}\right)$ is below approximately 1.5 times the minute ventilation $(\dot{V} E) .^{1-3}$ It has been argued that rebreathing is harmful for patients during spontaneous breathing ${ }^{4}$ but it can be used to avoid hypocapnia during controlled ventilation. ${ }^{5.6} \mathrm{~A} \dot{V}_{\mathrm{FG}} / \dot{\mathrm{V}}_{\mathrm{E}}$ ratio of $0.5-0.6$ has been suggested for use in controlled ventilation and a fresh gas flow of $70 \mathrm{ml} \cdot \mathrm{min}^{-1} \cdot \mathrm{kg}^{-1}$ in combination with a minute ventilation of at least $120 \mathrm{ml} \cdot \mathrm{min}^{-1} \cdot \mathrm{kg}^{-1}$ has been shown to result in normocapnia in adults. ${ }^{7.8}$

During laparoscopy, carbon dioxide is normally insufflated into the abdomen of the patient. Some of this gas is absorbed by the blood vessels and eliminated through the lungs. This increased carbon dioxide elimination must be compensated for by a higher alveolar ventilation if normocapnia is to be maintained. When a Bain circuit and a rebreathing technique are used, the fresh gas flow must consequently be set higher than normally used. ${ }^{2,6}$ An increase in carbon dioxide is also seen during pregnancy. Duncan $e t$ al. found that a fresh gas flow which was about 40 per cent higher than that normal resulted in normocapnia during late pregnancy when the Mapleson D system and controlled ventilation were used. ${ }^{9}$ There is no general recommendation as to how much the VंFG should be increased during laparoscopy. The aim of this study was to investigate whether a $\dot{V}_{F G}$ of $110 \mathrm{ml} \cdot \mathrm{min}^{-1} \cdot \mathrm{kg}^{-1}$ in controlled ventilation would be sufficient to produce a predictable normocapnia.

\section{Methods}

Twenty-two females (19-50 years of age) were studied during laparoscopy for diagnostic reasons $(n=21)$ or for sterilization $(n=1)$. Demographic data are presented in Table I and the protocol was approved by the Ethical Committee for Human Research at Östersund Hospital.

All patients were premedicated with oral diazepam $(0.2$ $\left.\mathrm{mg} \cdot \mathrm{kg}^{-1}\right)$ and IM meperidine $\left(1 \mathrm{mg} \cdot \mathrm{kg}^{-1}\right)$. Thiopentone, low-dose fentanyl (0.1-0.2 mg IV) and muscle relaxants (succinylcholine, pancuronium, alcuronium or atracurium) were used for induction of anaesthesia. The breathing system used was a Bain circuit (Coax II, Mediplast AB, Solna, Sweden) and 33 per cent oxygen in nitrous oxide was administered with the addition of isoflurane, 0.5-1 
TABLE I Patients' demographic data.

\begin{tabular}{llll}
\hline & $\begin{array}{l}\text { Body weight } \\
\mathrm{kg}\end{array}$ & $\begin{array}{l}\text { Height } \\
\mathrm{cm}\end{array}$ & $\begin{array}{l}\text { Age } \\
\text { years }\end{array}$ \\
\hline Mean & 59.0 & 167.0 & 33.4 \\
\pm s.d. & 6.4 & 5.3 & 8.5 \\
Range & $49-71$ & $158-178$ & $19-50$ \\
\hline
\end{tabular}

per cent, in eight patients. The fresh gas flow was set at $110 \mathrm{ml} \cdot \mathrm{min}^{-1} \cdot \mathrm{kg}^{-1}$ from calibrated rotameters. Controlled ventilation was provided by a bag-in-bottle ventilator (UV 705, Siemens-Elema AB, Solna, Sweden). The $\dot{V}_{\mathrm{E}}$ was set to $175 \mathrm{ml} \cdot \mathrm{min}^{-1} \cdot \mathrm{kg}^{-1}$ and measured by means of a Wright spirometer connected between the anaesthetic system and the ventilator. The respiratory rate was set at 14 breaths $\cdot \mathrm{min}^{-1}$.

After preparation of the skin, the surgeon introduced a trochar into the abdomen and carbon dioxide was insufflated at a flow rate of approximately $1 \mathrm{~L} \cdot \mathrm{min}^{-1}$. When the intra-abdominal pressure was $1.3 \mathrm{kPa}(10 \mathrm{mmHg})$, insufflation was stopped and the laparoscope was introduced. The volume of carbon dioxide insufflated was within the range of 3.5-4.5 L. At the end of the operation but before the abdomen was exsufflated, a blood sample was taken from the radial artery. This sample was immediately stored in ice water and analysed (ABL 3, Radiometer, Copenhagen, Denmark) within 30 minutes. The elapsed time from the start of carbon dioxide insufflation until the blood sample was taken ranged from ten to 45 minutes, and for 18 of the 22 cases it was between 20 and 30 minutes. Normocapnia was defined as a $\mathrm{PaCO}_{2}$ within the range of $4.7-5.9 \mathrm{kPa}(35-45 \mathrm{mmHg})$. This correlates with the mean normal value of $5.3 \mathrm{kPa} \mathrm{(40}$ $\mathrm{mmHg}$ ) found in non-anaesthetized volunteers \pm three standard deviations approximately. ${ }^{10}$

\section{Results}

The results from the blood-gas samples are summarized in Table II. The anaesthetic procedure was uncomplicated in all cases and all patients did well. Normocapnia was found in 19 of the 22 patients with a mean $\mathrm{PaCO}_{2}$ of 5.1 $\mathrm{kPa}(38 \mathrm{mmHg})$ and a range of $4.4-6.2 \mathrm{kPa}(33-46.5$ $\mathrm{mmHg}$ ). The resulting mean $\mathrm{pH}$ was 7.41 with a range of 7.35-7.49.

\section{Discussion}

There are several reasons to preserve normocapnia during anaesthesia. Hypocapnia will increase vascular resistance and decrease cardiac output and the amount of oxygen available in the myocardium, while hypercapnia may produce cardiac arrhythmias. ${ }^{11,12}$ With a rebreathing technique and controlled ventilation, normocapnia is relatively easy to achieve since the resulting $\mathrm{PaCO}_{2}$ is influenced mainly by the delivered fresh gas flow. ${ }^{2,6}$ In normal patients a $\dot{V}_{F G}$ of $70 \mathrm{ml} \cdot \mathrm{min}^{-1} \cdot \mathrm{kg}^{-1}$ results in normocapnia in most North American patients if the $\dot{V}_{E}$ is at least $120 \mathrm{ml} \cdot \mathrm{min}^{-1} \cdot \mathrm{kg}^{-1} \cdot 7,8$ The resulting $\mathrm{PaCO}_{2}$ in Scandinavia is somewhat higher ${ }^{13}$ and we normally use a $\dot{V}_{F G}$ of $75 \mathrm{ml} \cdot \mathrm{min}^{-1} \cdot \mathrm{kg}^{-1}$ in controlled ventilation to achieve normocapnia. ${ }^{14}$ The reason for this discrepancy between North Americans and Scandinavians is unknown, but may be related to dietary differences. A lower fat content will produce a higher respiratory quotient which will result in higher carbon dioxide elimination.

In situations where carbon dioxide elimination is increased, the rebreathing technique demands an increase in fresh gas flow in order to obtain normocapnia. ${ }^{6}$ Since the ratio between $\dot{V}_{F G}$ and $\dot{V}_{E}$ in a Bain circuit during controlled ventilation should be below 1.0 when a rebreathing technique is used, a simultaneous increase in $\dot{V}_{E}$ will be necessary. The amount of carbon dioxide absorbed from the abdomen during laparoscopy is unknown, but an increase in $\dot{V}_{F G}$ of about 40 per cent when a Mapleson D system is used has been demonstrated to compensate for the increased carbon dioxide elimination that occurs during late pregnancy. ${ }^{9}$ If the increase in carbon dioxide elimination were known, the StenquistSonander formula for calculating end-tidal fractions in the Bain circuit could be used to find out the degree to which the $\dot{V}_{F G}$ should be increased. ${ }^{15}$ According to this formula, a proposed 40 per cent increase in carbon dioxide elimination could almost completely be compensated for by a 40 per cent increase in VFG and a constant $\dot{V}_{F G} / \dot{V}_{E}$ ratio of 0.6 , provided $\dot{V}_{D} / \dot{V}_{T}$ ratio and the inspiratory/expiratory time fractions were unaltered. This means that the $\dot{V}_{F G}$ would be increased from 75 to 105 $\mathrm{ml} \cdot \mathrm{min}^{-1} \cdot \mathrm{kg}^{-1}$ and the $\mathrm{VE}$ would be increased from 125 to $175 \mathrm{ml} \cdot \mathrm{min}^{-1} \cdot \mathrm{kg}^{-1}$. The results of the present study show that these assumptions are valid during laparoscopy. Eighty-six per cent of the patients were found to be normocapnic at the end of the carbon dioxide insufflation period when a $\dot{V}_{F G}$ of $110 \mathrm{ml} \cdot \mathrm{min}^{-1} \cdot \mathrm{kg}^{-1}$ and a $\dot{V}_{E}$ of $175 \mathrm{ml} \cdot \mathrm{min}^{-1} \cdot \mathrm{kg}^{-1}$ were applied. The mean $\mathrm{PaCO}_{2}$ was somewhat lower than that normally found in a nonanaesthetized healthy population. ${ }^{10}$ If the demonstrated discrepancy between Scandinavian and North American populations is taken into account, this corresponds to a

TABLE II Results of the blood-gas analyses

\begin{tabular}{lllll}
\hline & $p H$ & $\begin{array}{l}\mathrm{PaCO}_{2} \\
\mathrm{kPa}\end{array}$ & $\begin{array}{l}\mathrm{PaO} \\
\mathrm{kPa}\end{array}$ & $\begin{array}{l}\mathrm{BE} \\
\mathrm{mmol} \cdot \mathrm{l}^{-\prime}\end{array}$ \\
\hline Mean & 7.41 & 5.1 & 24.1 & 0.1 \\
s.d. & 0.03 & 0.5 & 2.8 & 1.5 \\
95\% conf. & 0.01 & 0.2 & 1.2 & 0.6 \\
\hline
\end{tabular}


$\dot{V}_{F G}$ of approximately $100 \mathrm{ml} \cdot \mathrm{min}^{-1} \cdot \mathrm{kg}^{-1}$ and a $\dot{V}_{E}$ of $170 \mathrm{ml} \cdot \mathrm{min}^{-1} \cdot \mathrm{kg}^{-1}$ in a North American population.

We conclude that the basic recommended fresh gas and minute ventilation flows in a Mapleson D system should be increased by approximately 45 per cent in women undergoing laparoscopic procedures with $\mathrm{CO}_{2^{-}}$ insufflation of the abdomen in order to compensate for the increased carbon dioxide elimination. If these higher flows are used, a predictable normocapnia will result.

\section{Acknowledgments}

This study was performed with the help of grants from the Health Science Research Foundations of the County Council of Jämtland, Abbott Scandinavia and the AGA Medical Foundations.

\section{References}

I Mapleson WW. The elimination of rebreathing in various semi-closed anaesthetic systems. $\mathrm{Br} \mathrm{J}$ Anaesth 1954: 26: 323-32.

2 Conway $C M$. Anaesthetic breathing systems. Br J Anaesth 1985: 57: 649-57.

3 Dorrington $K L$, Lehane $J R$. Minimum fresh gas flow requirements of anaesthetic breathing systems during spontaneous ventilation: a graphical approach. Anaesthesia 1987: 42: 732-7.

4 Byrick $R J$. Respiratory compensation during spontaneous ventilation with the Bain circuit. Can Anaesth Soc J 1980: 27: 96-105.

5 Ayre $P$. Endotracheal anaesthesia for babies: with special reference to hare-lip and cleft palate operations. Anesth Analg 1937: 16: 330-40.

6 Seeley $H F$, Barnes $P K$, Conway $C M$. Controlled ventilation with the Mapleson D system. A theoretical and experimental study. Br J Anaesth 1977: 49: 107-14.

7 Bain JA, Spoerel WE. Flow requirements for a modified Mapleson D system during controlled ventilation. Can Anaesth Soc J 1973: 20: 629-36.

8 Bain JA, Spoerel WE. Prediction of arterial carbon dioxide tension during controlled ventilation with a modified Mapleson D system. Can Anaesth Soc J 1975: 22: 34-8.

9 Duncan PW, Lawes EG, Bland B, Downing JW. Fresh gas flow requirements using the ADE anaesthetic system during late pregnancy. Br J Anaesth 1987: 59; 360-3.

10 Geigy Scientific Tables, Vol. 3, pp. 71-77, 1984.

11 Utting JE. Hypocapnia. In: Gray TC, Nunn JF, Utting JE: General Anaesthesia. 4th edition. Butterworths, London, 1980, pp A61-76.
12 Robertsson $B J$, Clement $J L$, Knill RL. Enhancement of the arrythmogenic effect of hypercarbia by surgical stimulation during halothane anaesthesia in man. Can Anaesth Soc J 1981: 28: 342-9.

13 Bain $J A$, Dick W, Englesson $S$ et al. Does geographical location influence inflow requirements of the Bain breathing system? Eur J Anaesthesiol 1984: 1: 37-43.

14 Jonsson $L O$. Predictable normo- and mild hyperventilation with the coaxial Mapleson D system in adults. Acta Anaesthesiol Scand 1987: 31: suppl, 86, 152.

15 Stenquist $O$, Sonander $H$. Rebreathing characteristics of the Bain circuit. An experimental and theoretical study. Br J Anaesth 1984: 56: 303-10.

\section{Résumé}

Nous avons évalué chez 22 femmes, la performance du circuit de Bain au cours de laparoscopies avec insuffation abdominale au $\mathrm{CO}_{2}$. Le débit de gaz frais ( $\left.\dot{V}_{\mathrm{FG}}\right)$ érait ajusté à $110 \mathrm{ml}$. $\mathrm{min}^{-1} \cdot \mathrm{kg}^{-1}$ et la ventilation minute ( $\left.\dot{V}_{E}\right)$ en mode contrôlé érait de $175 \mathrm{ml} \cdot \mathrm{min}^{-1} \cdot \mathrm{kg}^{-1}$. Nous avons fait des analyses de gaz artériels d la fin de l'intervention et trouvé que: 19 des femmes (86 pour cent) avaient une $\mathrm{PaCO}_{2}$ normale $44.7-5.9 \mathrm{kPa}$ ou 33-45 $\mathrm{mmH}$ ), deux étaient en hypocarbie avec des $\mathrm{PaCO}_{2}$ de 4.4 et $4.5 \mathrm{kPa}(33$ et $34 \mathrm{mmHg})$ et une seule avait une $\mathrm{PaCO}_{2}$ élevée d $6.2 \mathrm{kPa}(46.5 \mathrm{mmHg})$. Il semble donc qu'avec l'absorption du $\mathrm{CO}_{2}$ contenu dans l'abdomen pendant une laparoscopie, il faille augmenter le débit de gaz frais du circuit de Bain au deld des normes habituelles si l'on veut maintenir une $\mathrm{PaCO}_{2}$ normale. En fait, une augmentation du débit de gaz frais et de la ventilation minute de 45 pour cent devrait suffire. 